\title{
石狩湾新港における防波堤周辺の \\ 海浜変形について \\ ON BEACH CHANGES AROUND BREAKWATER \\ IN THE NEW PORT OF ISHIKARI BAY
}

\author{
戸 巻 昭 ${ }^{1}$ - 竹 沢 三 雄 ${ }^{2}$ \\ Shozo TOMAKI and Mitsuo TAKEZAWA
}

\begin{abstract}
${ }^{1}$ 正会員 株式会社クマシロシステム設計（=060-0807 札幌市北区北 7 条西 2 丁目 8)
${ }^{2}$ フエロー会員 工博 日本大学教授 理工学部土木工学科（テ101-8308 東京都千代田区神田駿河台 1-8）
\end{abstract}

\footnotetext{
The single space beach change around breakwaters in the new port of Ishikari Bay is described using the beach profiles of field surveying.

The following properties was made clear after examining the results of field surveying:

(1) the shoreline and the equilibrium point of beach profile are relating to the grain size of beach sands,

(2) the trough depth is proportional to the bar depth and they are relating to the steepness of wave breaker,

(3) the changes of shoreline is effected by the wave reflection, and is related by the site of trough and bar.
}

Key Words : breakwater, change of beach, field survey.

\section{1. はじめに}

防波堤などにより沿岸漂砂移動の連続性が崩れると 漂砂の下手側海岸で侵食が起きることは一般によく知 られている. 現在, 防波堤の遮蔽域でみられる海岸線 の侵食機構を海浜変形の予測システム ${ }^{1)}$ により解 明が行われているが，現地のデータを用いて汀線変化 を含め海浜地形の侵食と堆積について，防波堤を境に その両側で比較した研究例 ${ }^{2)}$ は比較的少ない。

本研究は, 防波堤の存在によって形成される地形変化 について, 石狩湾新港の東側及び西側海岸における海浜 断面の地形変化に関する現地調査の結果から考察し たものである.

\section{2. 石狩海岸の地形と現地調査の範囲}

\section{（1）石狩海岸の地形}

北海道の日本海に面する石狩湾新港は, 図一 1 に示す ように石狩湾奥に位置している.この石狩湾新港周辺の 石狩海岸の特徵は, 石狩川からの流出土砂が長い年月を 経て堆積し形成された平野部と, 隆起によって生じた急 峻な海崖（石狩段丘）とからなっている.このうち, 砂
浜海岸は銭函〜知津狩間約 $24 \mathrm{~km}$ にわたって連続してい る. 石狩湾の海底地形は, 水深 $20 \mathrm{~m}$ まで, その等深線

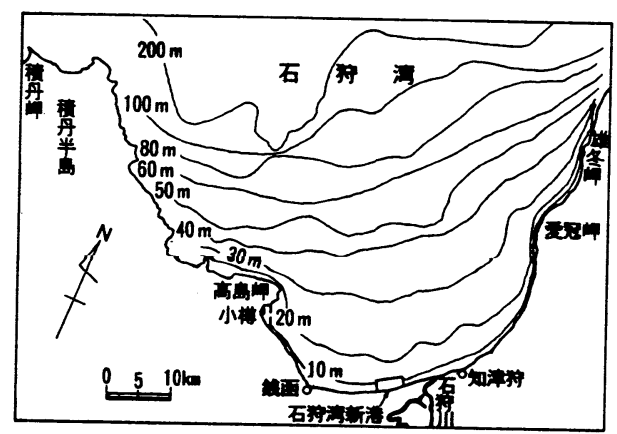

図-1 石狩海岸の位置図

が湾奥地形とほぼ平行し，その海底勾配は著しく遠浅 な形状を示している．そして石狩湾はその開口部を $\mathrm{N}$ W方向に開いており, 日本海からの高波浪はこのNW 方向から入射する.

また, 石狩湾岸の長期的な汀線変化は, 明治 29 年 （1896） と昭和 48 年 (1973) の地形図 $(1 / 50,000)$ を 重ね合わせてみたが, 殆どその汀線変化は認められな かった. 


\section{（2）現地調查の範囲}

調查の対象区域は，図一 2 に示すように,石狩湾新港 により海浜地形が影響を受けると思われる東防波堤よ り右側 (東側海岸) $3,500 \mathrm{~m}$ の範囲と,西地区埋立護岸 より左側 (西側海岸) $3,500 \mathrm{~m}$ の範囲の海岸を, それぞ れ 3つの領域（東側海岸第 1 領域 $\mathrm{R}-0, \mathrm{R}-2$. 第 2 領域 $R-4, R-6$. 第 3 領域 $R-8, R-10$. 西側 海岸第 1 領域 $\mathrm{L}-21, \mathrm{~L}-23$. 第 2 領域 $\mathrm{L}-25, \mathrm{~L}$ -28. 第 3 領域 L-30，L-33.）に区分し,各領域で 実施された深浅測量図 ${ }^{3)}$ から，それぞれ2本の側線を選び， 沿岸砂州が存在する合計 152 本 (うち 6 本は沿岸砂州の形 成なし）の海浜断面地形より防波堤周辺の海浜変形につい て考察した。

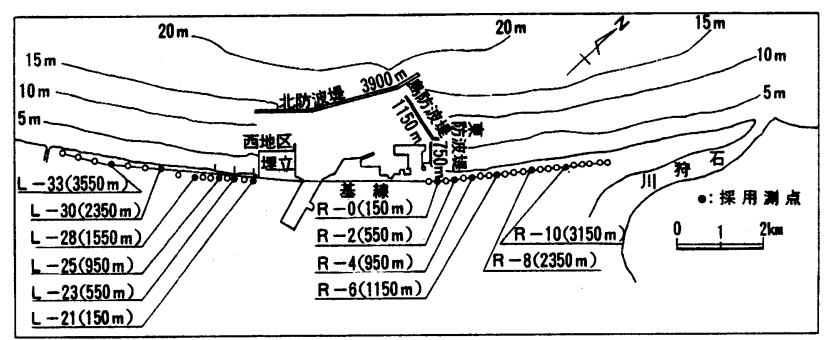

図-2 石狩海岸の調査範囲

なお，深浅測量による地形図のうち， R-0, R-2, R -4 及びL $-21, \mathrm{~L}-23, \mathrm{~L}-25, \mathrm{~L}-28$ は，一側線につ き 1984 年から 1991 年までの 8 年間に 7 8 月と 12 月の年 2 回実測 $L, R-6, R-8, R-10$ 及び $L-30, L-33$ は一側線につき, 7 8 月の年 1 回実測されたものである.

\section{3. 波浪条件}

石狩海岸の波浪は，石狩湾新港沖合 $5 \mathrm{~km}$ の地点 $(-24$ m) で北海道開発局により観測されている. 図一 3は, こ の観測より得られた観測期間 5 ケ年 (1989 1993) の波向 別波高 $\left(\mathrm{H}_{1,3} \geqq 3.0 \mathrm{~m}\right)$ の出現頻度を示したものである.

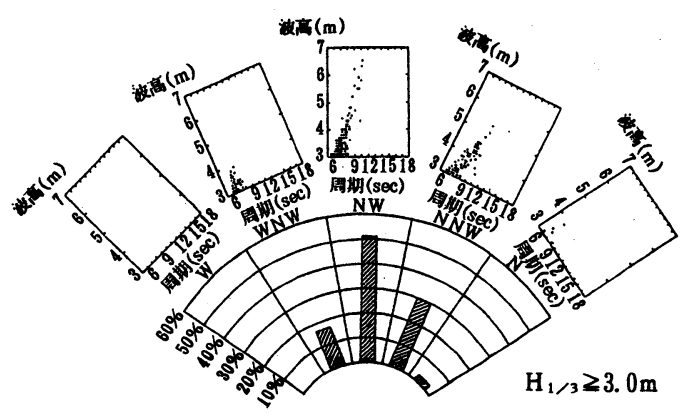

図－3 石狩海岸波向別波高出現頻度分布

一方，短期的に海浜地形に作用した波の諸元は，深浅測 量の実測当月と前月のうち約 2 日間連続して生じた異常波 浪の最大有義波浪 $\left(\mathrm{H}_{1 / 3}, \mathrm{~L}_{1 / 3}\right)$ に起因するものとし ${ }^{4)}$, その波浪条件を波浪観測台帳から求めた。なお, 想定した 波の諸元 (Ho, Lo) と研波 (Hb, Lb) の関係は, 図-4 のとおりである.

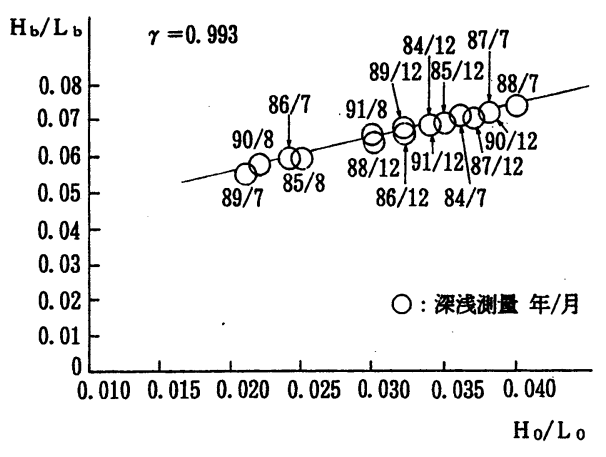

図-4 沖波と砕波の関係

\section{4. 石狩海岸の海浜地形}

\section{（1） 東側海岸の海浜地形}

現在, 石狩湾新港周辺の地形変化のうち, 防波堤の遮蔽 域と考えられる東側海岸は堆積性であり, 一方西側海岸で は侵食性を示す。このように, これら 2 つの海岸が石狩湾 新港を境に非刘称性となっている. 表一 1 は石狩湾新港施 設とその施工期間を示したものである.

\section{表-1 石狩湾新港施設と施工期間}

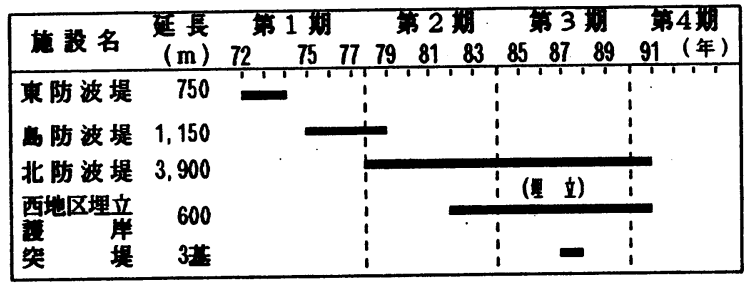

昭和 47 年 (1972) 測点 $\mathrm{R}-0$ から西方向 $150 \mathrm{~m}$ 地点の石 狩海岸に初めて東防波堤が施工され，地形測量も同時に 実施された。

図一 5 に示すように測点 $\mathrm{R}-0$ の汀線は，東防波堤の施 工に伴い前進し，表一 1 に示す第 2 期から第 3 期では逆に 後退し続けたが, 第 4 期では再度堆積性に転じ, 現在 $150 \mathrm{~m}$ 程汀線が前進している.

図一 5 に示す $\mathrm{R}-0$ の汀線変化のコレログラムは，その 中に小さな曲線が重複して生じており，これは長期的に平 衡性が保たれていた石狩海岸に防波堤の建設により，海浜 地形変化を誘起させたことを示している。

次に, $\mathrm{R}-0$ から $800 \mathrm{~m}$ 離れた $\mathrm{R}-4$ の汀線変化は, $\mathrm{R}$ -0 と同様に第 2 期から第 3 期で汀線は後退するが, 第 4 期に入り回復し，当初と殆ど同じ位置に存在している.

一方， R-8 の汀線変化は，北防波堤工事の後半，第 3 期より影響が出始め，これをコレログラムでみると 3〜4 年周期で侵食と堆積が繰り返され，防波堤による汀線変化 がほとんど及んでないことを示している。

また，図一 5に示すようにR-0, R-4そしてR-8 の 海浜断面地形で海底の砂汃顕著に移動しない平衡点 ${ }^{5)}$ を平 面図にプロット (O印) すると, $R-0$ から平衡点 (水深 $11.0 \mathrm{~m})$ まであった離岸距離は次第に短くなり, 汀線から 平衡点までの海浜断面地形は汀線の前進に追随している.

防波堤の影響による海浜地形変化のうち, 平衡点の形成 
位置と汀線変化との関連性をみるために 1998 年 12 月, 汀 線底質粒径調査を $500 \mathrm{~m}$ 毎に行った。

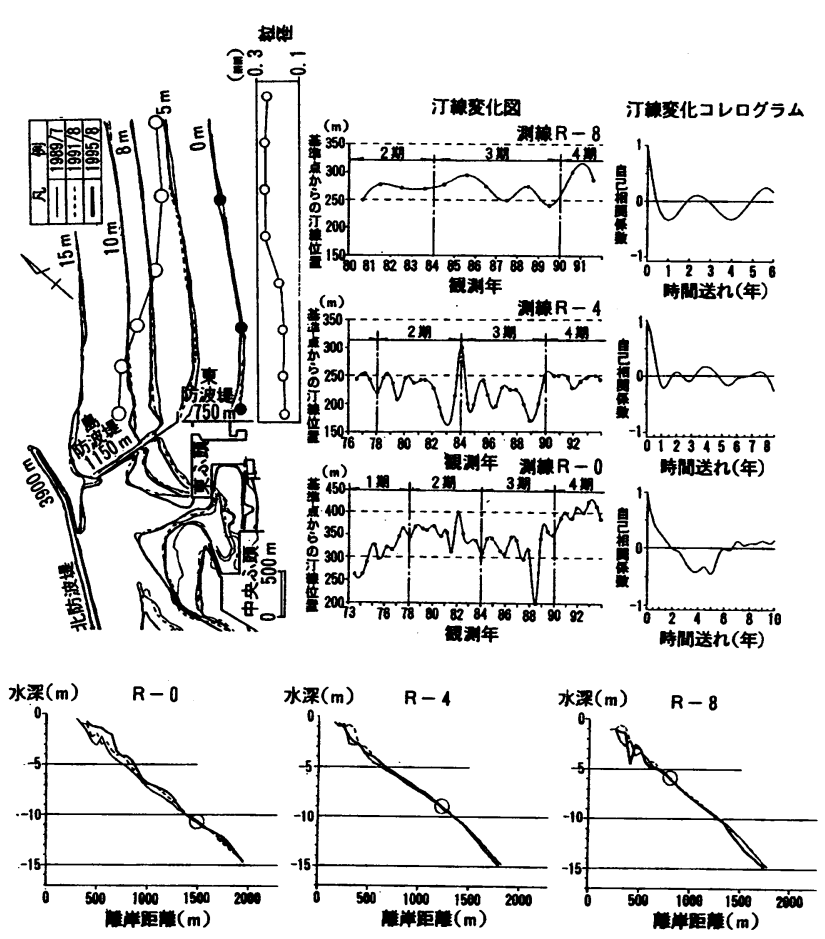

図-5 東側海岸の平面・断面及び汀線変化の対比

図一 5 に示す底質粒径は，堆積性の第 1 領域と平衡性の 高、第 3 領域で底質粒径に差が認められることから，明ら かに東側からの沿岸漂砂移動があったものと考えられる.

また，北防波堤先端付近において入射する WNW 方向 の波浪が東側海岸の第 2 領域加東防波堤方向に弱い流れ を生じさせ，さらに北防波堤背面で時計迴りの方向に大規 模な循環流 ${ }^{6)}$ が生じることが予想されるので, 汀線底質粒 径はそれらの流れに呼応した分布状態力形成されたものと 推測される.

\section{（2） 西側海岸の海浜地形}

図一 6 に示す西側海岸の海浜地形が東側海岸と大きく異 なるのは, 東防波堤及び島防波堤に引き続いて行われた北 防波堤の建設に伴って, 地形変化が東側海岸より西側海岸 方向に伝播してきたことによるものである. 港湾の建設に より沿岸漂砂が遮られ，当初L-21 から $150 \mathrm{~m}$ まであった 海岸線は北防波堤が $2,000 \mathrm{~m}$ 程伸長された時から急激に侵 食し始め, 1986 年には $100 \mathrm{~m}$ にまで後退した. そして,こ の対応策として 1987 年突堤 3 基が設置され，さらに西地 区埋立護岸の建設によって L-21 付近だけが堆積し，現 在では当初より $100 \mathrm{~m}$ 程汀線が前進している.

しかし, 第 3 突堤基部のL -25 では, 突堤の設置後も 汀線はやや安定するが, 第4 期に入ると急激に後退し始め, 現在では当初より $50 \mathrm{~m}$ 程後退している. 次に, 西地区埋 立護岸より $1,350 \mathrm{~m}$ にある $\mathrm{L}-27$ の汀線変化は, 殆ど港湾 構造物の影響はなく，測点から水際線まで $150 \mathrm{~m}$ の距離は 当初のまま維持されている.したがって, コレログラムの 形は, 東側海岸の R-4 とやや類似しており, 防波堤によ る西側海岸の海浜地形変化は $\mathrm{L}-27$ 付近が境界であるも のと考えられる.

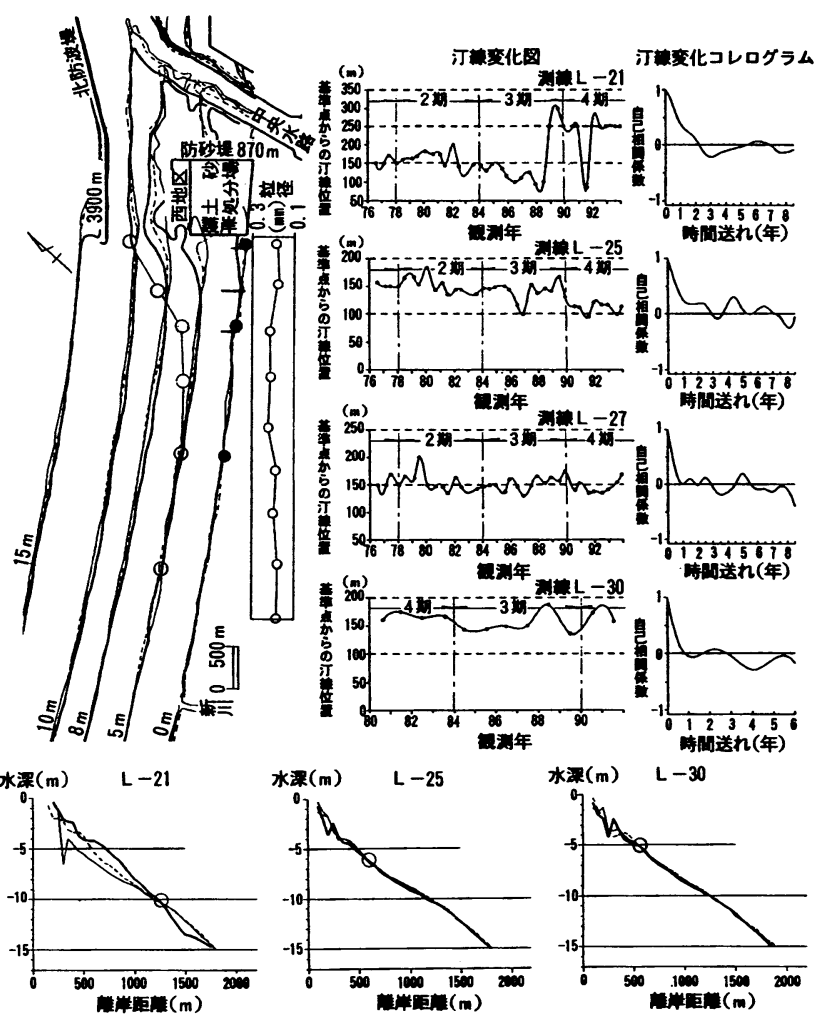

図-6＼cjkstart西側海岸の平面・断面及び汀線変化の対比

また，L-30 の汀線変化図とコレログラムは東側海岸 $\mathrm{R}-8$ と非常に類似し，この付近では，ほとんど北防波堤 による影響はないものと考えられる。

次に, 東側海岸と同様に L $-21, \mathrm{~L}-25, \mathrm{~L}-30$ の海 浜断面地形に認められる平衡点を西側海岸の平面図にプロ ット（O印）してみると， L-30 付近で水深 5m に収束 していた平衡点が突堤 3 基付近から離岸距離が次第に増大 し，そしてL-21 では水深 $10 \mathrm{~m}$ にまで達している。これ は, 沖方向に漂砂移動幅を拡大し, 東側海岸と同様な現象 が生じているものと考えられる.

次に，汀線底質粒径分布と海浜地形との関連をみると， 西側海岸ではおおよそ同じ粒径で構成されているが, 第 3 突堤のL-25 から西へ $1,000 \mathrm{~m}$ （測点L-29）区間だけの 粒径がやや大きい.これは, N〜NNW方向からの波浪が 影響しているものと考えられる。

\section{（3）沿岸砂州と海浜地形}

港湾建設による前浜部分において，図一 5 ，図一6に見 られるようにいずれの海浜断面においても沿岸砂州が認め られる. そこでその規模や形成位置などが, どのように海 浜地形と関わりがあるのか, 東側及び西側の両海岸につい て考察する.

図一7に示すように沿岸砂州の大きさを表示する尺度と して, 沿岸砂州のトラフ水深 $\mathrm{h}_{\mathrm{T}}$, 頂部水深 $\mathrm{h}_{\mathrm{B}}$, 平衡点水 深 $\mathrm{h}_{\mathrm{C}}$, 基礎杭から最初の汀線までの距離 $\mathrm{a}_{\mathrm{O}}$ 及びその位置 より変形後の距離 $l a\left(a=l a+a_{0}\right)$, 変形後の汀線 よりバーまでの距離 $\ell_{\chi}$, バーから平衡点までの距離 $\ell_{\mathrm{b}}\left(\ell=\ell_{\chi}+\ell_{\mathrm{b}}\right)$ を与える.

図一8は沿岸砂州のトラフ水深 $\mathrm{h}_{\mathrm{T}}$ とバー頂部水深 $\mathrm{h}_{\mathrm{B}}$ の相関を東側海岸 (O) と西側海岸 (○) をパラメータ 


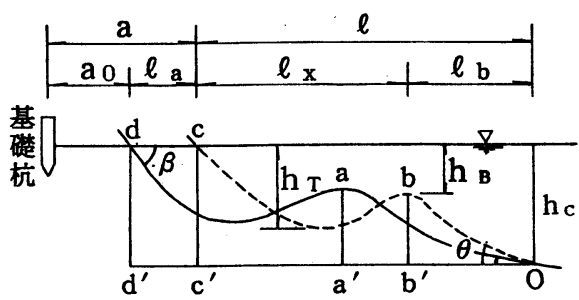

図-7 海浜断面と記号の定義

として示したものである. また, (1)は R $-0, R-2$ 及び $\mathrm{L}-21, \mathrm{~L}-23$ を，(2)はR $-4, \mathrm{R}-6$ 及びL $-25, \mathrm{~L}-$ 28 を，そして (3)は $\mathrm{R}-8, \mathrm{R}-10$ 及びL $-30, \mathrm{~L}-33$ について領域毎に示したものである.

図一8(1)(2)によると，西側海岸では東側海岸に比較し て全体的にトラフ水深やバ一頂部水深は大きいが，しかし 防波堤から遠ざかる図ー8(3)ではグループ別の区分線が 重複するようになり, 東西両海岸の差がほとんどない。

次に, 沿岸砂州の生成変動を支配する砕波 $\left(\mathrm{H}_{\mathrm{b}}, \mathrm{L}_{\mathrm{b}}\right)$ と, 比高 $\left(\mathrm{h}_{\mathrm{T}}-\mathrm{h}_{\mathrm{B}}\right)$, 汀線からバーまでの距離 $\left(\ell_{\chi}\right)$ の関係について考察する.

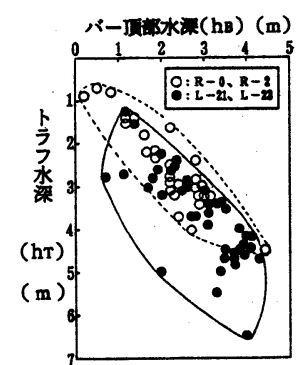

(1)

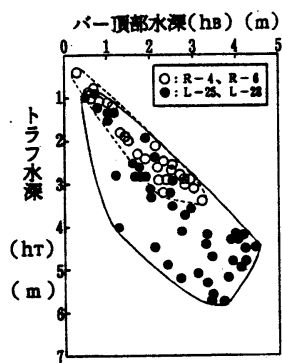

(2)

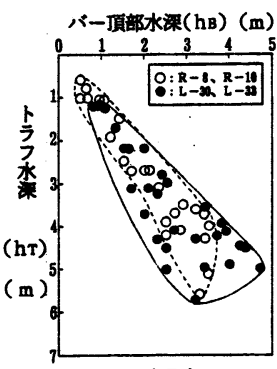

(3)
図ー8 対比する領域毎の沿岸砂州の規模

図-9はR-0, R-2, R-8, R-10 及びL $-21, \mathrm{~L}$ $-23, \mathrm{~L}-30, \mathrm{~L}-33$ の $\left(\mathrm{h}_{\mathrm{T}}-\mathrm{h}_{\mathrm{B}}\right) / \mathrm{H}_{\mathrm{b}}$ と $\left(\ell_{\chi} / \mathrm{L}_{\mathrm{b}}\right)^{2}$ の関係を示したものである.

図一 9 から, 沿岸砂州の形成位置は $\left(\mathrm{h}_{\mathrm{T}}-\mathrm{h}_{\mathrm{B}}\right) / \mathrm{H}_{\mathrm{b}}$ と $\left(\ell_{\chi} / \mathrm{L}_{\mathrm{b}}\right)^{2}$ によって,ある程度その傾向をみることが できる.すなわち，図一 9 から砕波 $\left(\mathrm{H}_{\mathrm{b}}, \mathrm{L}_{\mathrm{b}}\right)$ に対す る地形変化の応答が早いのは, 直線群の傾きが急な両海岸 とも第 3 領域 $(\mathrm{R}-8,10$ 及びL $-30,33)$ における沿岸 砂州で，ここは防波堤に関係なく直接波浪の影響を受ける 海岸である.これに対し応答が遅いのは直線群の傾きが緩 い第 1 領域 $(\mathrm{R}-0,2$ 及びL-21，23）で，いずれも防 波堤の有無が地形変化の応答に関わっていることが明らか である.

しかし，同じ防波堤に近い海浜であっても，沿岸砂州規 模を示す比高に差が認められ，この比高が東・西側海岸の 海浜地形の変化に影響があるものと考えられる.

本間ら ${ }^{7)}$ は, 前浜部分の変動について東海村海岸での資 料から, 比高の大きい砂州ほど連続した規模が大きく, 逆 に小さいと不連続の部分が現われ，トラフについても波高 の大きい程連続した水路状を呈するが，小さい場合にはポ ケット状の凹地が点在するにすぎないと報告している.

一方, kuriyama ${ }^{8)}$ は, 鹿島灘海岸での沿岸流の観測の
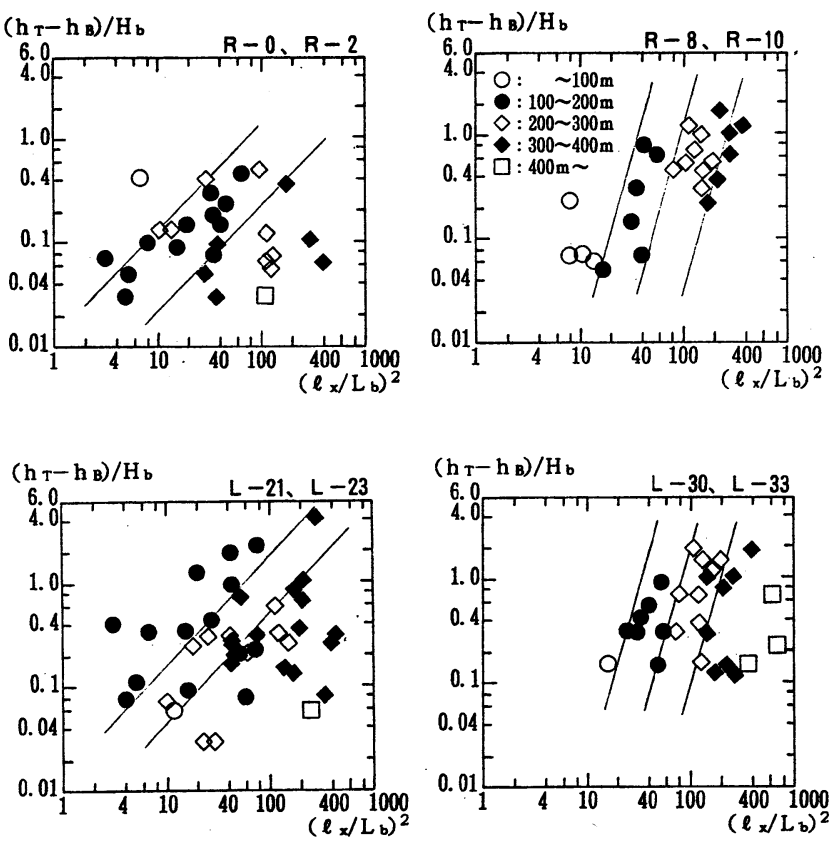

図-9 東・西海岸の比高と相対距離の関係

結果, 沿岸流速のピークがバー頂部より岸側に位置した分 布形が全体の 85\%であったことを報告している.

この 2 つ現地の事例から,石狩湾新港の西側海岸の海 浜地形が侵食性となるのは, 東側海岸よりも沿岸砂州の卜 ラフ水深やバ一頂部水深が大きいため, バ一頂部より岸側 の沿岸流速が早く，かつ比高の大きいバーやトラフが連続 した水路状を呈していることが原因と考えられる.

\section{（4）汀線変化と沿岸砂州移動}

石狩湾新港における東・西側海岸の海浜地形の相違は, 沿岸砂州移動によるものであり, その外力の一つとして海 岸からの波による反射率 $(\gamma)^{9)}$ が考えられる.

そこで現地の海岸での反射率を Battjes ${ }^{10)}$ の波の反射

$$
\gamma=0.1 \tan ^{2} \beta / \mathrm{H}_{\mathrm{b}} / \mathrm{L}_{\mathrm{b}}
$$

率から求め, 図-10 にその頻度分布を東・西側海岸の領 域毎に示した.なお，（）は海浜断面数である.

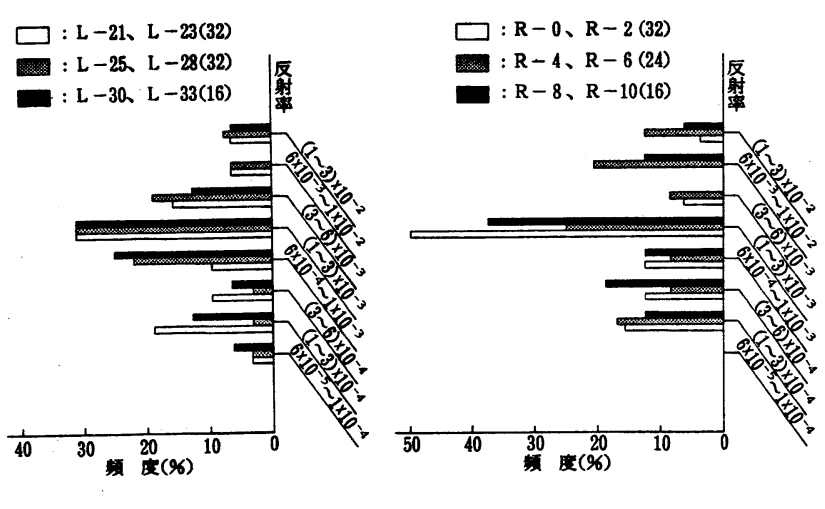

図-10 各領域の反射率

また, 海浜勾配 $(\tan \beta)$ は, 汀線以深の斜面勾配 $(\beta)$ である. 


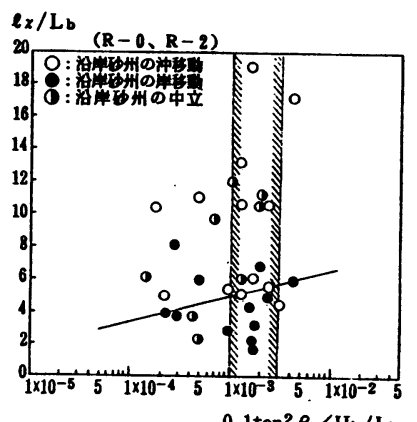

(1)

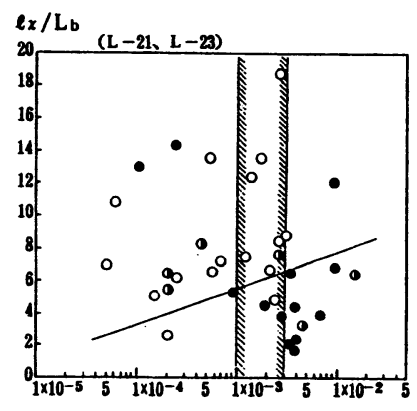

(2)
図-11 反射率と相刘波長の関係 (第1 1 領域)

図-11 は $\gamma$ と $\ell_{x} / \mathrm{L}_{\mathrm{b}}$ の関係に沿岸砂州の岸・沖移動 の方向をパラメータとして示したものであり, かなりばら つきはあるものの, 海底地形変化の様相を大きく変化させ る沿岸砂州の岸 ・沖移動方向の移動限界は, 図中の直線で おおよそ区分できるものと考えられる.また，沿岸砂州の 岸・沖移動方向は, 図一11に示すモード $(1 \sim 3) \times 10^{-3}$ の
反射率の範囲で大部分形成されるほか, 西側海岸の第 1 領 域では反射率が小さい程, つまり海浜勾配 $(\tan \beta)$ が緩 くなると沿岸砂州の沖移動が多くなっている.

図-12 は, 海岸からの波による反射率 $(\gamma)$ と関係の 深い汀線変化率 $\left(a_{0}-a\right) / a$ と $\left(l_{x} / \ell\right)$ との関係 であり, 東側海岸における沿岸砂州の岸・沖方向への移動 が, 各領域とも汀線の前進・後退に関係なく $\ell_{x} / \ell<0.2$ では沿岸砂州は岸移動し, $\ell_{x} / \ell>0.2$ では沖移動の傾 向を示している. また西側海岸でも，第 2 , 第 3 領域の $\ell_{\chi} / \ell$ は東側海岸ほど明確でないが, 東側海岸とほぼ同 様の傾向を示している. しかし，西側海岸の第 1 領域にお いては，汀線が前進すると沿岸砂州は沖移動し，後退する と岸移動になる傾向があり，かなり複雑な海浜移動がある ものと考えられる.これは，この領域に海浜移動制御のた め設置した 3 本の突堤の影響を受けて，図一8及び図ー9 に示すように沿岸砂州規模による沿岸流流速の大きい分布 が存在することと, 図一11 から海浜勾配 $(\tan \beta)$ が小さ

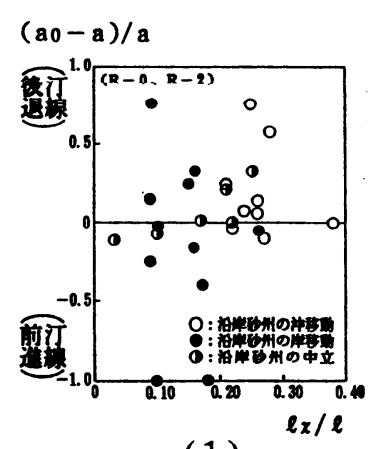

(1)

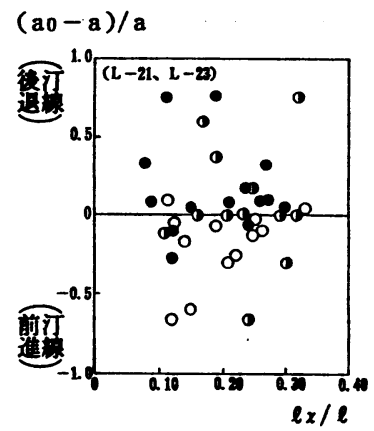

(4)

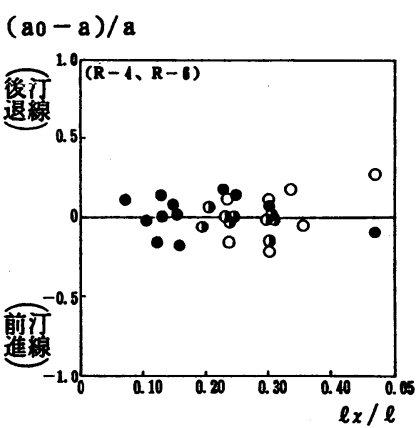

(2)

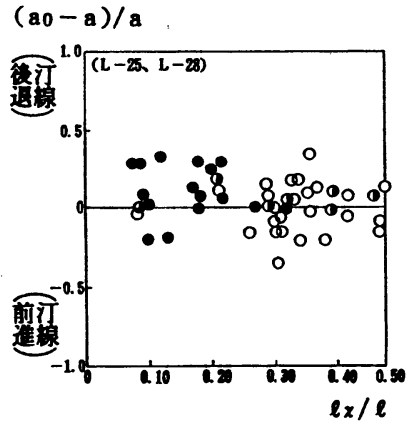

(5)

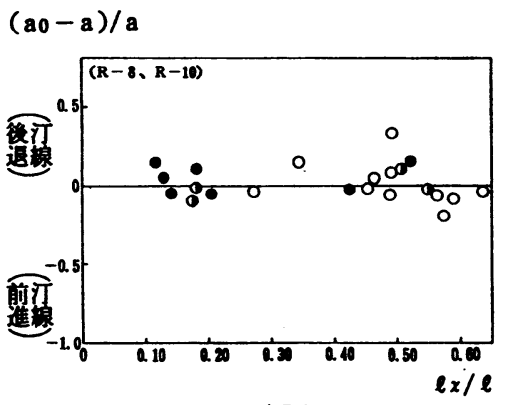

(3)

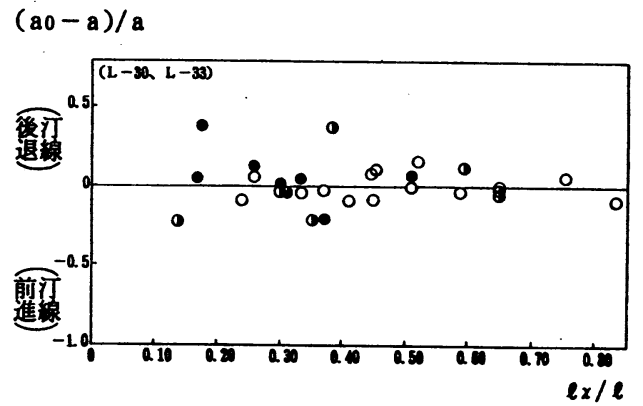

(6)

図-12 各領域における汀線変化率と相対距離の関係

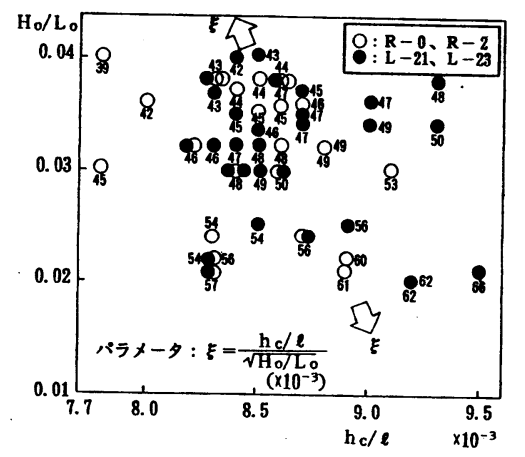

(1)

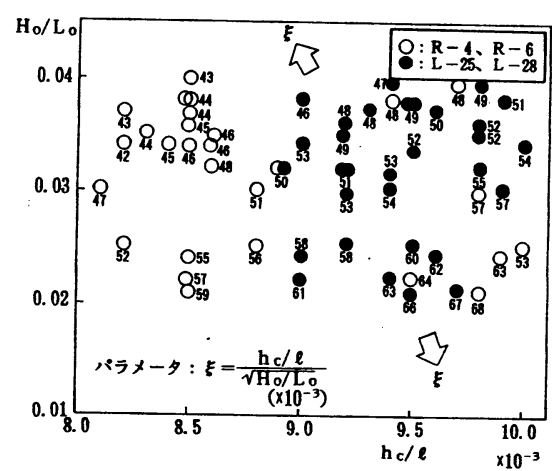

(2)

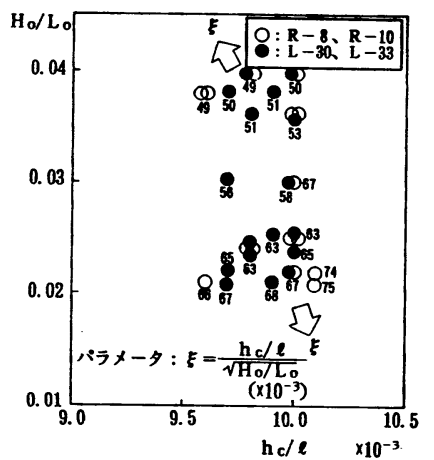

(3) 
$い^{11)}$ ほど沿岸砂州の沖移動が西側海岸の第 1 領域におい て顕著に現れるからと考えられる。

（5）平衡点に関する海底勾配 $(h \mathrm{c} / \ell)$

現在，波による海浜変形を論ずるにあたって，海浜断面 変形モデルにいくつかの海底勾配 12）13）14）15）16) が用 いられている.そこで本研究では，現地海岸への取扱いと して最も妥当な平衡点をべースに，平衡点 ( $\mathrm{hc}$ c) と汀線 から平衡点までの距離 $(\ell)$ の比を海底勾配 $(\mathrm{hc} / \ell)$ とした.この海底勾配は平衡点までの海底地形の規模を表 示していることになる.

図-13 は，沖波波形勾配( $\mathrm{H}$ o/ $\mathrm{L}$ o ) と海底勾配 $(\mathrm{h} \mathrm{c} /$ り)の関係を東・西側海岸の各領域毎に集約し，砕波帯相 似パラメータ $\xi=\mathrm{hc} / \ell \sqrt{\mathrm{Ho} / \mathrm{LO}}$ をパラメータ17) にして示したものである.

四-13(3)から，防波堤の影響を受けない東・西側海岸の 海浜地形は共に入射波の波形勾配に関係なく海底勾配

$(\mathrm{h} \mathrm{c} / \mathrm{l})=10 \times 10^{-3}$ 付近に平衡点を形成する傾向が 強い.

次に図一-13(2)より防波堤の影響を受け始めると，東側 海岸(堆積性)は西側海岸(侵食性)の海底勾配( h c / l) よ り小さくなり，緩勾配を形成する.ささら，図-13(1)より 防波堤の影響を完全に受けるようになると，東・西両海岸 で区分ができなくなるが，波形勾配に関係なく，hc/l $=8.0 \times 10^{-3} \sim 9.0 \times 10^{-3}$ に分布している. なお，砕波帯 相似パラメー夕 $\xi=39 \times 10^{-3} \sim 75 \times 10^{-3}$ である.

\section{5. むすび}

現地調查結果から，防波堤周辺の海浜変形について定量 的な検討を試みたが, その結果は次のように要約される.

（1）石狩湾新港の東側及び西側海岸における汀線変化のコ レログラムと平衡点との平面的な形成位置の関係は，汀線 の底質粒径と関係がある。

（2）西側海岸は東側海岸に比較して全体的にトラフ水深 $\left(h_{\mathrm{T}}\right)$ とバー頂部水深 $\left(\mathrm{h}_{\mathrm{B}}\right)$ は共に大きく, かつ侵食 の程度が大きい。これは沿岸流速のピークがバ一頂部より 岸側に位置し, かつ比高 $\left(\mathrm{h}_{\mathrm{T}}-\mathrm{h}_{\mathrm{B}}\right)$ の大きい沿岸砂州の 形成が原因と考えられる.

(3)東側海岸と西側海岸の第 2, 第 3 領域では, 汀線の前 進・後退に関係なく $\ell_{x} / \ell<0.2$ で沿岸砂州は岸方向に 移動し, $\ell_{x} / \ell>0.2$ で沖方向に移動する.一方, 海浜 勾配 $(\tan \beta)$ の小さい西側海岸の第 1 領域では, 汀線が 前進すると沿岸砂州は沖方向に移動し, 後退すると岸移動 に変る傾向がある.

(4)防波堤の影響を完全に受ける領域では，東・西側海岸 に関係なく波形勾配（Ho／Lo）の大きい場合には海底 勾配 ( $\mathrm{hc} / \mathrm{l})$ が小さく, 波形勾配 (Ho/Lo) が小 さくなると海底勾配 ( $\mathrm{hc} / \mathrm{l})$ が大きくなる. また，防
波堤の影響が小さい領域になると東側海岸 (堆積性) では, 西側海岸 (侵食性) の海底勾配 ( h c / l ) より緩勾配を 形成する.さらに，防波堤の影響のない領域では海底勾配 は波形勾配に関係なく h c $/ \ell=10 \times 10^{-3}$ となる.

（5)石狩湾新港の海岸付近における研波帯相似パラメータ $\xi=39 \times 10^{-3} \sim 75 \times 10^{-3}$ である.

\section{参考文献}

1） Nicholas C. Kraus, 針貝聡一, 久保田進 : 大洗海 岸における汀線変化シミュレーション, 第 28 回海講 論. PP.295〜299, 1981.

2）針貝聡一，宇多高明，鶴川義郎：大洗海岸における 地形変化の観測, 第28 回海講論. PP.271 275, 1981.

3）北海道開発局 : 石狩湾新港深浅測量 (1972 1997) 図資料.

4） 戸巻昭三，竹沢三雄 : 現地観測による汀線と沿岸砂 州の移動過程について, 海洋海講論 vol.14, PP.173 $\sim 178,1998$

5）久宝雅史, 戸巻昭三: 海浜横断面の平衡点について, 第28 回海講論. PP.247〜250, 1981.

6）宇多高明，山本幸次：波向が周期的に変化する場に おける防波堤周辺の海浜変形, 第 39 回海講論. PP.436 〜40, 1992.

7） 本間仁, 堀川清司, 鮮干徹 : 波浪・漂砂及び海浜変 形について, 第6回海講集. PP.78〜88, 1959.

8) kuriyama Y.and 0zaki : Longshore current distribution on a bar-trough beach-Field measurements at HORF and numerical model, Rep. Port and Harbour Res. Inst., vol.32, N0.3, PP.3 $\sim 37,1993$.

9) 前出 4)

10) Battjes, J.A.: Surf similarity, Proc. 14th Conf. on Coastal Eng., PP.466 480, 1974.

11) 水村和正:防波堤背後の流況と汀線変化(2), 第 26 回 海講論. PP.195 199, 1979.

12）堀川清司，砂村継夫，近藤浩右，岡田滋：波による 二次元汀線変化に関する一考察, 第 22 回海講論. PP.329 334, 1975.

13）砂村継夫 : 自然海浜における汀線位置の時間的変化 に関する予測モデル，第 27 回海講論. PP.255〜259， 1980.

14）椹木亨 : 漂砂と海岸浸食, PP.124 125, 共立出版, 1982.

15）尾崎晃，电田信一：波による二次元汀線変化の相似 に関する実験的研究 (続)，第 24 回海講論. PP.167〜 $169,1977$.

16）服部昌太郎，川又良一: 砕波帯内の海浜変形過程, 第 25 回海講論. PP.218 222, 1978.

17）水村和正: 海岸海洋工学, PP.58 64, 共立出版, 1992. 